\title{
Five Veins at the Deep Inguinal Ring. Can they Reduce the Chances of Indirect Inguinal Hernia and Increase the Chances of Varicocele?
}

\author{
Cinco Venas en el Anillo Inguinal Profundo. ¿Pueden Reducir las Probabilidades \\ de una Hernia Inguinal Indirecta y Aumentar las Posibilidades de Varicocele?
}

Satheesha B. Nayak

\begin{abstract}
NAYAK, S. B. Five veins at the deep inguinal ring.can they reduce the chances of indirect inguinal hernia and increase the chances of varicocele? Int. J. Morphol., 37(2):682-684, 2019.

SUMMARY: Complete duplication of testicular veins is a rare phenomenon. However, a few cases of duplication of gonadal veins have been reported. Here, I report a case of unusual formation and termination of the right testicular vein in an adult male cadaver. Five veins arose from the pampinniform plexus and entered the abdomen through the deep inguinal ring. The most medial among the five was large ( $3 \mathrm{~mm}$ in diameter) and it continued as a testicular vein and opened into the right edge of the inferior vena cava, $1 \mathrm{~cm}$ above the union of the common iliac veins. The other four veins were about $1 \mathrm{~mm}$ in diameter and they united to form two veins in front of the lower part of the right psoas and iliacus muscles (about $2 \mathrm{~cm}$ above the deep inguinal ring) and the two veins united to form upper testicular vein, $4 \mathrm{~cm}$ above the deep inguinal ring. This testicular vein was $3 \mathrm{~mm}$ in diameter and it opened into the inferior vena cava, 4 $\mathrm{cm}$ above the union of common iliac veins. Having five veins at deep inguinal ring might increase the chances of varicocele and decrease the chances of indirect inguinal hernia.
\end{abstract}

KEY WORDS: Testicular vein; Gonadal vein; Inferior vena cava; Deep inguinal ring; Hernia; Surgery.

\section{INTRODUCTION}

Venous drainage of the testis is through the pampiniform plexus of veins. The pampiniform plexus is found within the spermatic cord. It reduces to four veins near the superficial inguinal ring and into two veins near the deep inguinal ring and into a single testicular vein at variable levels in the abdomen. Mode of termination of testicular veins is different on two sides of the body. Left testicular vein terminates into the left renal vein and the right into the inferior vena cava. The variations in the mode of origin or termination of testicular veins are rare. Functionally, these variations could pose a risk of development of a varicocele and thus resulting in infertility. These variations could complicate the surgical and radiological procedures too. Therefore, documentation of all possible variations is of importance. This report presents, an unreported variation of right testicular vein. Aim of the report is to alert the urologists and radiologists about the presence of five unusual veins at the deep inguinal ring.

\section{CASE REPORT}

During dissection classes for undergraduate medical students, I observed a case of unusual formation and termination of the right testicular vein in an adult male cadaver aged approximately 60 years. The pampiniform plexus of veins condensed to form five veins in the inguinal canal, near the deep inguinal ring. These five veins entered the abdomen through the deep inguinal ring. The most medial among the five was larger than other veins $(3 \mathrm{~mm}$ in diameter) and it continued as lower right testicular vein and opened into the right edge of the inferior vena cava, $1 \mathrm{~cm}$ above the union of the common iliac veins (Figs. 1 and 2). The other four veins were about $1 \mathrm{~mm}$ each in diameter and they united to form two veins in front of the lower part of the right psoas and iliacus muscles (about $2 \mathrm{~cm}$ above the deep inguinal ring) and the two veins united to form upper testicular vein, $4 \mathrm{~cm}$ above the deep inguinal ring. This testicular vein thus formed was $3 \mathrm{~mm}$ in diameter and it opened into the anterior surface of the inferior vena cava, 4 


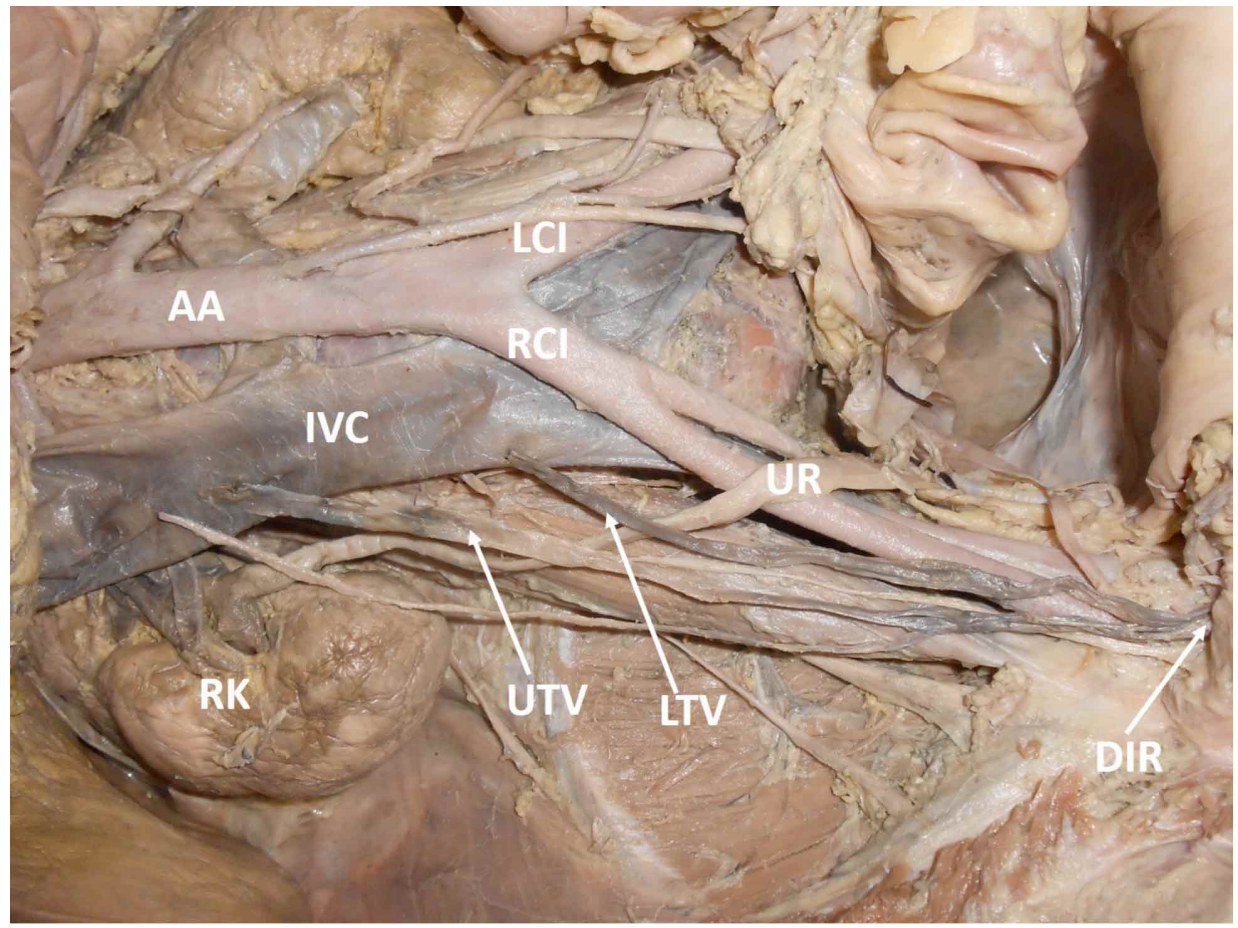

Fig. 1. Dissection of the lower part of the posterior abdominal wall, showing duplication of the right testicular vein. AA - abdominal aorta; IVC - inferior vena cava; RCI - right common iliac vein; LCI - left common iliac vein; UTV - upper testicular vein; LTV - lower testicular vein; UR - right ureter; DIR - deep inguinal ring; RK - right kidney.

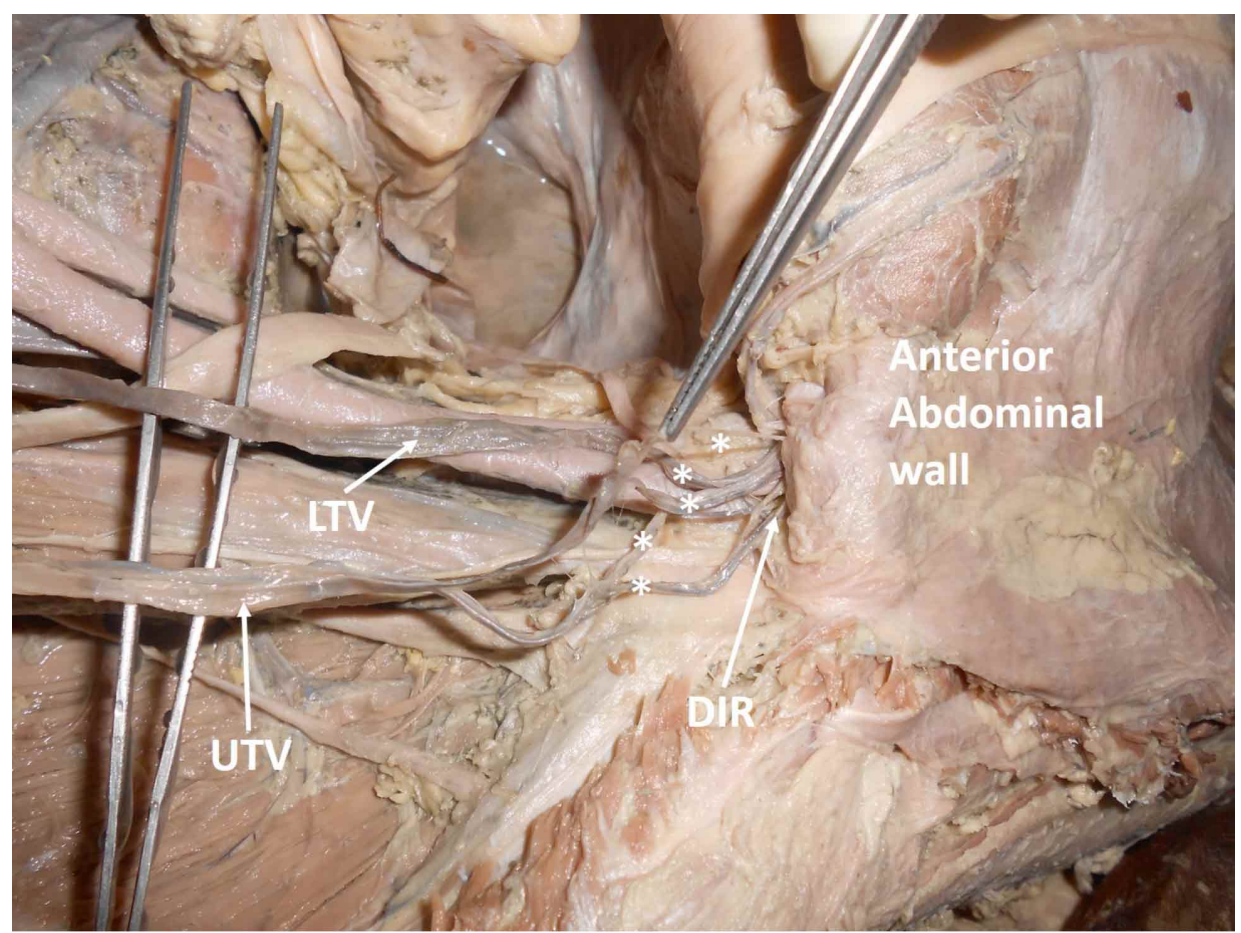

Fig. 2. Dissection of the lower part of the abdomen near the deep inguinal ring, showing five veins (marked with asterisks) emerging out from the deep inguinal ring. Anterior abdominal wall has been cut and reflected. UTV - upper testicular vein; LTV - lower testicular vein; DIR - deep inguinal ring. $\mathrm{cm}$ above the union of common iliac veins. The pampiniform plexus was slightly dilated.

\section{DISCUSSION}

Reported variations of the testicular vein include its duplication (Abraham et al., 2015) and terminal bifurcation (Nayak et al., 2013). In a study by Favorito et al. (2007), duplication of right testicular vein was found in in $5 \%$ of the cases. Lalwani et al. (2017) have studied the gonadal veins with reference to their number, mode of termination and angulation of termination. They opine that duplication the ends, anomalous drainage site, and varied angles of termination can cause problems in the procedures which use terminal ends of gonadal veins as entry portals. Gupta et al. (2015), noticed either duplication or atypical termination of the testicular vein in $45 \%$ of the individuals. In a recent study by Mazengenya (2016), the right testis had four testicular veins. One of them drained into the subcostal vein, two of them joined shortly before draining into the right main renal vein, the fourth one drained into the anterior aspect of the inferior vena cava. Mao \& Li (2017) have reported the trifurcation of the testicular vein and the passage of bifurcated testicular artery between them. There is no report in the available literature about the entry of five veins of different sizes from inguinal canal to abdomen. In the current case, the deep inguinal ring was 
clogged with five testicular veins. Ultimately only two testicular veins drained into the inferior vena cava. The mode of their termination was also different. The upper one opened through the anterior surface of the inferior vena cava, whereas the lower one opened through the right edge of the inferior vena cava.

The presence of five veins at the deep inguinal ring apart from other structures like vas deference, testicular artery and the lymphatics might hinder the venous drainage of the testis and thus result in varicocele. We can also hypothesize that due to the presence of so many structures at the deep inguinal ring, the chances of having an indirect inguinal hernia could be reduced.

\section{CONCLUSION}

This report presents a rare variation of the right testicular vein. Presence of five testicular veins at the deep inguinal ring; formation of two testicular veins in the abdomen and their variant termination into the inferior vena cava is the main feature of this report. This pattern of testicular veins might lead to a varicocele and the veins could also be damaged during retroperitoneal procedures. The variant termination might hinder the embolization procedure of testicular veins. This case could be of special interest to radiologists and urologists.

NAYAK, S. B. Cinco venas en el anillo inguinal profundo. ¿Pueden reducir las probabilidades de una hernia inguinal indirecta y aumentar las posibilidades de varicocele?. Int. J. Morphol., 37 (2):682-684, 2019.

RESUMEN: La duplicación completa de las venas testiculares es un fenómeno raro. Sin embargo, se han reportado algunos casos de duplicación de venas gonadales. En el presente trabajo se informa un caso de formación y terminación inusual de la vena testicular derecha en un cadáver de un hombre adulto. Cinco venas surgieron del plexo pampiniforme y penetraron en el abdomen a través del anillo inguinal profundo. El más medial entre los cinco fue de gran tamaño (3 mm de diámetro) y continuó como una vena testicular y se abrió hacia el margen derecho de la vena cava inferior, $1 \mathrm{~cm}$ por encima de la unión de las venas ilíacas comunes. Las cuatro venas restantes eran de $1 \mathrm{~mm}$ de diámetro aproximadamente, y se unieron para formar dos venas frente a la parte inferior de los músculos psoas e ilíaco derechos (aproximadamente $2 \mathrm{~cm}$ por encima del anillo inguinal profundo). Se unieron dos venas para formar la vena testicular superior, la cual medía $3 \mathrm{~mm}$ de diámetro y se abría hacia la vena cava inferior, $4 \mathrm{~cm}$ por encima de la unión de las venas ilíacas comunes. Cinco venas en el anillo inguinal profundo podrían aumentar las posibilidades de varicocele y disminuir las posibilidades de una hernia inguinal indirecta.

PALABRAS CLAVE: Vena testicular; Vena gonadal; Vena cava inferior; Anillo inguinal profundo; Hernia; Cirugía.

\section{REFERENCES}

Abraham, J.; Sharma, A.; Sharma, M.; Jessy, J. O. \& Priyanka. Duplication of right testicular vein: embryological and clinical consideration - A case report. J. Clin. Diagn. Res., 9(11):AD03-04, 2015.

Favorito, L. A.; Costa, W. S. \& Sampaio, F. J. Applied anatomic study of testicular veins in adult cadavers and in human fetuses. Int. Braz. J. Urol., 33(2):176-80, 2007.

Gupta, R.; Gupta, A. \& Aggarwal, N. Variations of gonadal veins: embryological prospective and clinical significance. J. Clin. Diagn. Res., 9(2):AC08-10, 2015.

Lalwani, R.; Athavale, S. A.; Chauhan, K.; Nigam, G. L.; Babu, C. S. R. \& Kotgirwar, S. Cadaveric study of mode of termination of gonadal veins: Implications for procedures utilizing terminal ends of gonadal veins as entry portals. J. Nat. Sci. Biol. Med., 8(2):210-2, 2017.

Mao, Q. H. \& Li, J. Double right testicular arteries passing through the hiatus in the trifurcated testicular vein. Indian J. Surg., 79(1):73-4, 2017.

Mazengenya, P. Multiple variations of the renal and testicular vessels: possible embryological basis and clinical importance. Surg. Radiol. Anat., 38(6):729-33, 2016.

Nayak, B. S.; Rao, K. M.; Shetty, S. D.; Sirasanagandla, S. R.; Kumar, N. \& Guru, A. Terminal bifurcation of the right testicular vein and left testicular arterio-venous anastomosis. Kathmandu Univ. Med. J. (KUMJ), 11(42):168-70, 2013.

Corresponding author:

Satheesha B Nayak

Professor of Anatomy

Melaka Manipal Medical College (Manipal Campus)

Manipal Academy of Higher Education

Madhav Nagar, Manipal.

Karnataka State

INDIA

Email: sathish.nayak@manipal.edu

Received: 12-09-2018

Accepted: 04-02-2019 